\title{
"Eu tirava conclusão de uma nuvem pra outra": Uma reflexão sobre histórias, saberes e culturas da pesca artesanal em Arraial do Cabo
}

\section{Maria Aparecida Gomes Ferreira'}

A presente discussão envolve as consideraçóes iniciais alcançadas no projeto de pesquisa intitulado "Histórias de vidas de pescadores: memórias, identidade social e patrimônio cultural" , proposto ao Programa Institucional de Bolsas de Iniciação Científica e Tecnológica (PIBICT) realizado no Instituto Federal de Ciência e Tecnologia do Rio de Janeiro (IFRJ) - Campus Avançado de Arraial do Cabo. Dialogando com a defesa de pesquisas e estudos interdisciplinares (Thompson, 1978, 2002; Moita Lopes, 2006), o objetivo do referido projeto é analisar a construção discursiva das identidades sociais ${ }^{3}$ dos pescadores de Arraial do Cabo por meio das narrativas que eles contam sobre si e sobre os demais pescadores. Cabe salientar que, nesse fazer, envolvemo-nos não apenas com histórias de vida, mas também com aspectos sociais e culturais da comunidade em questão, imbricados nas narrativas geradas (Thompson, 1978; Worcman e Pereira, 2006).

1 Doutoranda do Programa Interdisciplinar em Linguística Aplicada da UFRJ.

2 O referido projeto teve vigência em 2011-2012 e contou com a participação de um bolsista remunerado (Ronaldo) e de um bolsista voluntário (Raphael). Esse projeto nâao teve por finalidade investigar "como" o pescador fala (suas possíveis variantes linguísticas), mas como ele se constitui discursivamente como pescador e como constitui seus pares.

3 Não discutirei aqui teorias sobre identidades sociais por não ser esse o foco do presente artigo. Ressalto, contudo, a defesa de que as identidades são construídas discursivamente, de forma provisória, dependendo sempre do contexto e da alteridade em questão (Moita Lopes, 2002). 
Para iniciar a presente reflexão, destaco que inúmeras são as possíveis definiçóes do termo "cultura”, a depender do recorte teórico feito. Eagleton (2005, p. 9) enceta sua publicação definindo-a como "um conceito derivado do de natureza”, já que, inicialmente, o referido autor propóe uma distinção entre aquilo que é considerado natural (não produzido pelo ser humano) e aquilo que é cultural (produzido pelo ser humano). Em seguida, comenta que um dos significados originais de tal termo estaria associado ao de "lavoura ou cultivo agrícola”. Dando continuidade à discussão sobre o conceito de "cultura", o autor propóe que

a cultura pode ser aproximadamente resumida como o complexo de valores, costumes, crenças e práticas que constituem o modo de vida de um grupo específico. Ela é 'aquele todo complexo', como escreve o antropólogo E. B. Tylor, (...) 'que inclui conhecimento, crença, arte, moral, lei, costume e quaisquer outras capacidades e hábitos adquiridos pelo ser humano como membro de uma sociedade (Eagleton, 2005, p. 55).

Destaco essa citação porque defendo, neste trabalho, a definição de cultura como um conjunto de conhecimentos e costumes construídos por um dado grupo social e como tal entendidas como construçóes sociais, práticas sociais ou discursivas que perpassam as relaçóes e interaçóes sociais (Mills, 1997; Faraco, 2009; Moita Lopes, 2009). Entender cultura como prática discursiva $a^{4}$ permite analisá-la como construção discursiva (Mills, 1997), o que dialoga diretamente com a análise aqui pretendida sobre o discurso oral. Entretanto, antes de dar continuidade à discussão, considero pertinente fazer algumas breves apreciaçóes sobre meu entendimento de "construçóes discursivas", bem como sobre a relação estabelecida entre cultura, discurso, conhecimento e sociedade.

Ao definirmos cultura como valores, práticas sociais, saberes ou costumes de dado grupo social, estamos defendendo a diversidade de crenças e ethos. Essa defesa, contudo, há que ser balizada pelos princípios da ética (Fabrício, 2006; Moita Lopes, 2006), para que não caiamos na armadilha do relativismo cultural, em que tudo é possível e permitido. Eagleton (2005,

4 Discursos ou práticas discursivas são fenômenos sociais que envolvem interesses políticos e ideológicos e relaçôes de poder (Mills, 1997; Foucault, 1971). Contudo, não me aprofundarei nesses conceitos, na presente discussão, por não ser este o foco do presente artigo. 
p. 28), por exemplo, lembra-nos de que "pluralizar o conceito de cultura não é facilmente compatível com a manutenção do seu caráter positivo", já que isso poderia nos conduzir a ideias como "cultura da máfia", ou "cultura de tortura" . Nesse momento, afilio-me, então, ao pensamento de Moita Lopes ao propor que

não penso que vivemos em um mundo do 'vale-tudo', como algumas versôes céticas pós-modernas querem nos fazer acreditar, (...). Normas e valores refletem posiçóes discursivas específicas, o que, de modo algum, implica relativismo ético. Ao tratar todos os conhecimentos como modos singulares válidos de descrever ou construir o mundo social, a posição relativista esvazia a natureza interessada do conhecimento. (...) Sou da opinião de que, tendo em vista alternativas e significados existentes, é legítimo preferir uns e refutar outros (Moita Lopes, 2006, p. 103).

Refutar o relativismo epistemológico ou cultural (Santos, 2004) não implica, contudo, ignorar a visão sócio-constitutiva do discurso (Foucault, 1971), desde que tenhamos a ética como limite intransponível. Ratifico, assim, a defesa de que culturas e conhecimentos são construçóes sócio-discursivas, e como tal são sempre "uma forma de conhecer a nós mesmos e de criar possibilidades para compreender a vida social e outras alternativas sociais" (Moita Lopes, 2006, p. 104). Defendo, portanto, junto de Santos, que

em vez da renúncia à emancipação social, proponho a sua reinvenção. (...) Em vez do relativismo, proponho a pluralidade e a construção de uma ética a partir de baixo. Em vez da desconstrução, proponho uma teoria crítica pós-moderna, profundamente auto-reflexiva, mas imune à obsessão de desconstruir a própria resistência que ela funda (Santos, 2004, p. 19).

O que subjaz a esse entendimento de construção discursiva é a compreensão de linguagem como "sistema de açóes simbólicas realizadas em determinados contextos sociais e comunicativos, que produzem efeitos e conseqüências semânticas convencionais" (Fabrício, 2006, p. 57). Essa visão de linguagem concebe a realidade ou a sociedade não como um dado preexistente ou prediscursivo, mas como efeito do discurso que produzimos

5 Idem, ibidem. 
e no qual somos produzidos (Foucault, 1971; Mills, 1997; Fabrício, 2006). Desse modo, portanto, podemos dizer que os discursos constroem as subjetividades, porque se inscrevem em nossos corpos, moldando e regulando comportamentos por meio de reiteradas performances e repetiçóes, e circunscrevem quais são os sujeitos que podem falar em nome do conhecimento ou quais saberes são legitimados (Louro, 1997, 2008). Ou seja, “os corpos são marcados social, simbólica e materialmente - pelo próprio sujeito e pelos

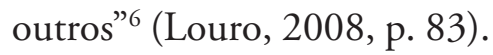

Não me furtei a trazer essas consideraçóes porque Alberti (2004, p. 9) critica alguns discursos que propóem que “a história é 'construção' (...) como sinônimo de 'não vinculada à realidade’: (em que) tudo é possível, pois tudo são versóes e 'construçóes' do passado". O questionamento dessa autora pode ser associado à crítica feita a algumas visóes pós-modernas que tudo relativizam. Embora reconheça a necessidade de reflexóes minuciosas sobre discursos relativistas, volto a defender a ideia de "construção discursiva”, alinhando-me a teóricos como Foucault (1971). De acordo com Mills (1997, p. 50), existe um grande debate sobre a questão se Foucault estaria negando a existência do real quando defende o poder sócio-constitutivo do discurso. Para essa autora, ao dizer que o discurso constitui sujeitos e objetos,

Foucault não está negando que existe uma realidade que preexista aos humanos, nem está negando a materialidade dos eventos e experiências, como alguns de seus críticos alegam; está apenas destacando que o único modo de apreender a realidade é através do discurso e estruturas discursivas. No processo de apreensão, nós categorizamos e interpretamos experiências e eventos de acordo com as estruturas disponíveis, e no processo de interpretação, nós atribuímos a essas estruturas a solidez e normalidade fora das quais é difícil pensar (Mills, 1997, p. 54).

Dialogando com Foucault, Faraco (2009, p. 49) lembra-nos também de que "o real nunca nos é dado de forma direta, crua, em si. (...) o mundo só adquire sentido para nós, seres humanos, quando semioticizado”. Nesse sentido, fica evidente que os limites do pensamento ou da compreensão/ interpretação são os limites da linguagem ou do discurso (Grayling, 1988)

6 Outras consideraçôes sobre a inscrição de discursos e práticas sociais em nossos corpos serão apresentadas no final da presente discussáo. 
e, por esse motivo, defendo que conhecimentos e culturas são construções discursivas historicamente situadas (Bakhtin, 1929; Mills, 1997; Louro, 1997; 2008; Faraco, 2009; Moita Lopes, 2009), que produzem efeitos sociais sobre as subjetividades e suas corporeidades.

Complementando essa ideia, Alberti (2004, p. 19) destaca a hermenêutica como base da história oral e cita que "saber compreender significa realizar um verdadeiro trabalho de hermeneuta, de interpretação" e, para tal, ressalto que são mobilizados discursos e estruturas discursivas (Foucault, 1971; Mills, 1997). A própria conceituação de natureza, segundo Eagleton (2005, p. 149), é cultural, já que o que denominamos natureza, "é sempre uma interpretação da natureza” (id.). Se uma conceituação é sempre uma interpretação, ela é sempre valorativa e ideológica (Faraco, 2009) e, por assim ser, coloca o ser humano no bojo de tal discussão, já que é este, com seus interesses e perspectivas, que a propóe. Mais ainda, destaco Eagleton quando afirma que "se a natureza é sempre de alguma forma cultural, então as culturas são construídas com base no incessante tráfego com a natureza que chamamos de trabalho" (Eagleton, 2005, p. 12).

Nesse momento, para entrelaçar a rede entre cultura, natureza e trabalho, destaco as atividades de pesca de uma comunidade do litoral brasileiro como foco da presente discussão. De acordo com Linsker e Tassara (2005, p. 13), pesca é "toda atividade de apropriação, seja por coleta, seja por cultura, de recursos naturais aquáticos, podendo ocorrer tanto em alto-mar e na beira da praia quanto na água doce dos rios e lagos". Complementando tal definição, Diegues e Arruda (2001 apud Silva 2010, p. 2) afirmam que essas "atividades de trabalho não apenas se encontram atreladas ao manejo do ambiente, mas, sobretudo, medidas por relaçôes históricas, sociais e, consequentemente, culturais". Para Diegues (2004 apud Silva, 2010), a pesca é uma atividade antiga e de grande importância não só econômica, mas também cultural e simbólica, já que algumas sociedades foram erguidas material e simbolicamente a partir dessa atividade. $\mathrm{O}$ foco da presente discussão são os pescadores artesanais, que, muitas vezes, são excluídos ou colocados à margem de certas práticas ou processos sociais (Callou, 2010; Silva, 2010) por serem considerados incultos, já que muitas vezes não têm acesso aos saberes formais e escolarizados.

A pesca artesanal costuma ser valorizada pelas comunidades tradicionais pelo baixo impacto causado ao meio ambiente e pelos aprendizados 
realizados na interação respeitosa com a natureza. Segundo Callou (2010), historicamente, nas comunidades pesqueiras, são desenvolvidas "formas particulares de conhecimento e de organização social para utilização dos recursos naturais e conservação dos ecossistemas brasileiros"” que não podem ser ignoradas. Mussoline (1972 apud Callou, 2010), por exemplo, ressalta os conhecimentos ambientais que o pescador tem sobre "os ventos, os movimentos das águas, os hábitos dos peixes, seu periodismo, a época e a lua adequada para pôr abaixo uma árvore ou lançar à terra uma semente, ou uma muda, ou colher o que plantou". Igualmente, Linsker e Tassara destacam que

o olhar atento no horizonte ou nas marcaçóes de terra, o pensamento imerso em cálculos intuitivos, a observação dos fenômenos e elementos da natureza e, especialmente, a capacidade de prever o movimento dos cardumes de peixes e o seu comportamento revelam uma compreensáo do espaço e do ambiente que vai além do que simples palavras podem explicar (Linsker e Tassara, 2005, p. 12).

Os pescadores artesanais, também conhecidos como praieiros, jangadeiros, caiçaras ou açorianos (Linker e Tassara, 2005, p. 29), geralmente são considerados povos tradicionais caracterizados pela rusticidade e simplicidade da tecnologia usada no seu dia a $\mathrm{dia}^{8}$. Ratificando a validade dos conhecimentos produzidos pelos pescadores, Linsker e Tassara (2005, p. 21) destacam que, por serem "habitantes tradicionais das regióes em que atuam, (esses pescadores) detêm grande conhecimento e domínio sobre o ambiente e suas possibilidades exploratórias". Esse conhecimento e saberes são construídos no cotidiano do trabalho, a partir da experiência prática (Silva, 2010) e geralmente transmitidos por meio da oralidade, de geraçáo em geração, até porque os moradores dessas comunidades, na maioria das vezes, apresentam alto índice de analfabetismo (Linsker e Tassara, 2005).

Acerca da baixa escolaridade, Callou (2010, p. 46-47) aponta que "a falta de uma educação básica nas comunidades de pesca, no passado e no presente, (...), reforça a ideia de uma cultura oral fortemente desenvolvida entre os pescadores brasileiros". Silva (2010, p. 5), contudo, destaca a im-

7 Idem, op. cit., p.47

8 Idem, ibidem. 
portância da oralidade tanto para pescadores como para pesquisadores, já que as histórias orais "transmitem a sociabilidade da comunidade na visão dos seus moradores, assim como possibilitam ao pesquisador o conhecimento sobre as práticas tradicionais da pesca presentes no cotidiano ou no passado". Ou seja, como proposto por Moita Lopes (2009, p. 17), a partir do discurso oral, ou da escuta das histórias orais, temos a oportunidade de compreender o idiográfico.

Corroborando esses pontos de vista, Thompson (2002, p. 9) afirma que a história oral envolve a "interpretação da história" e das mutáveis sociedades e culturas através da escuta das pessoas e do registro de suas lembranças e experiências". O referido autor destaca, ainda, o entendimento de história oral como "um método que sempre foi essencialmente interdisciplinar (...) uma forma fundamental de interação humana que transcende essas fronteiras disciplinares" $"$.

Em "A voz do passado", Thompson destaca que

a história oral não é necessariamente um instrumento para mudança (social), (...). Contudo, a história oral certamente pode ser um meio para transformar ambos: o conteúdo e o propósito da história. Ela pode ser usada para mudar o foco da história em si e sugerir novas áreas de investigação; (...), ela pode devolver um lugar central às pessoas que fizeram e vivenciaram a história, a partir de suas próprias palavras (Thompson, 1978, p. 3)

Nesse sentido, a história oral permite a compreensão de fenômenos sociais a partir de variadas perspectivas, tornando a análise não somente mais complexa e rica como também e, principalmente, mais democrática (Thompson, 1978; Alberti, 2004). Ainda discutindo as vantagens do trabalho com história oral, Thompson (2002, p. 13) destaca os benefícios de conciliar análises qualitativas e quantitativas nos estudos realizados. Embora reconheça a necessidade de olhar para as práticas locais e para o conhecimento situado (Thompson, 1978), a preocupação deste autor centra-se na necessidade de reflexão sobre as "implicaçôes quantitativas", característica

9 Nesse momento, prefiro dizer histórias, no plural, já que não buscamos a singularidade, mas a pluralidade nas vozes, interpretaçôes, visôes e narrativas.

10 Idem, op. cit., p.10. 
bastante peculiar ao paradigma positivista de pesquisa. Nesse tangente, destaco que, como linguista aplicada e engajada em pesquisas de cunho interpretativista, meu interesse não se centra sobre as generalizaçôes, mas sobre a compreensão de um conhecimento ou de um fenômeno social localmente situado (Moita Lopes, 2002, 2006, 2009; Faraco, 2009).

No paradigma positivista ou no pensamento modernista, as pesquisas, por estarem interessadas em replicações, não consideram questôes locais, propondo teorizaçóes ou conclusóes muito distantes da vida real, que analisam e descrevem um sujeito a-histórico e prediscursivo (Venn, 2000). Com o advento da virada discursiva/somática, em meados do séc. XX, o discurso, o corpo e o conhecimento local ganharam papel de destaque nos estudos sociais e linguísticos, pois passamos a entender que "somos os discursos em que circulamos: eles nos fazem e constroem, ou seja, a linguagem não nos representa simplesmente, mas nos constrói” (Moita Lopes, 2009, p. 15). Desse modo, conforme proposto inicialmente, defendo a visão sócio-constitutiva do discurso e destaco que os conhecimentos, os significados, os discursos e as interpretaçóes são sempre contingenciais, provisórios e historicamente situados (Wortham, 2001; Moita Lopes, 2006, 2009; Louro, 2008; Faraco, 2009). Em diálogo, portanto, com Moita Lopes (2009, p. 16), destaco que meu interesse se encontra sobre o "conhecimento altamente contextualizado, que particulariza o foco da pesquisa com o olhar no qualitativo, no etnográfico e no singular".

Mais ainda, ressaltando não somente a situacionalidade de toda prática social, mas também a necessidade de um viés interdisciplinar para compreensão dos fenômenos sociais, como destacado por Thompson (1978), Moita Lopes (2009) afirma que

para estudar as práticas interacionais, nas quais os discursos são construídos, são essenciais conhecimentos que vêm de campos outros que aqueles da área da linguagem, já que somente teorizaçôes e metodologias do campo da linguagem não podem dar conta dos conhecimentos requeridos para estudar o discurso em interaçáo ou para investigar como as pessoas agem umas com as outras por meio da palavra em suas práticas (idem, op.cit., p. 16).

Tendo em vista os construtos acima discutidos, gostaria de chamar atenção para a força das narrativas que ouvimos e que contamos sobre nós e sobre 
os outros (Wortham, 2001; Moita Lopes, 2002; Worcman e Pereira, 2006). Nesse momento, destaco Sant'anna (2011, p. 14), ao afirmar que "somos seres que ouvem e contam histórias". Acrescenta, ainda, que "o ser humano é não apenas um ser que conta histórias, e ouve histórias, mas, sobretudo, que faz história. Fazer história é a suprema audácia dos humanos" ${ }^{11}$. Fazer história significa que, quando narramos nossas experiências, estamos nos engajando sócio, política e historicamente no discurso com outros interlocutores (reais ou potenciais) (Moita Lopes, 2002; Worcman e Pereira, 2006; Faraco, 2009). Entendo ser de suma importância essa observação, porque, por vezes, é comum pensar sobre a história como um conjunto de fatos passados com o quais não necessariamente temos relação direta, restando a nós, tấo somente, ouvi-los, catalogá-los ou nos lembrarmos deles. E, assim, esvaziamos a responsabilidade sócio-política que temos ao "fazer história". Quando aproximamos a história do momento presente e do cidadâo comum, por entender que hoje estamos construindo a história e que o fazemos por meio do discurso, recuperamos e ressaltamos a nossa participação social e política nessa construção e, por conseguinte, ressaltamos nossas responsabilidades sociais e compromissos éticos (Thompson, 1978; Venn, 2000; Santos, 2004; Moita Lopes, 2006, 2009; Worcman e Pereira, 2006; Faraco, 2009). De acordo com Thompson (1978, p. 9), ao ampliarmos o foco da investigação para as ações cotidianas e o cidadão comum, "o processo de escrever a história muda junto com seu conteúdo. $\mathrm{O}$ uso de evidência oral rompe com as barreiras entre analistas e o público em geral". Thompson destaca, ainda, que

a relação entre história e comunidade não deveria ser unilateral em qualquer direção, mas na verdade uma série de trocas, uma dialética, entre informação e interpretação, entre educadores e suas localidades; (...). Haverá espaço para muitos tipos de história oral e isso terá muitas diferentes conseqüências sociais. Mas no final, elas estão todas relacionadas (Thompson, 1978, p. 23).

Ainda acerca da relação dialética entre história e comunidade, bem como entre passado e presente, corroboro o argumento de Worcman e Pereira, de que,

11 Idem, op.cit., p. 14. 
independentemente de sua relação com o passado, toda história é sempre uma narrativa organizada por alguém (seja uma comunidade, um historiador, um órgão oficial ou a própria mídia), em determinado tempo e implica em uma seleção de fatos e personagens. Toda história tem um autor ou autores que selecionam e articulam os registros da memória. Nesse sentido, ainda que todos concordemos que a história 'fala' do passado, a construção da narrativa histórica ocorre invariavelmente no presente (Worcman e Pereira, 2006, p. 202).

Assim, quando narramos a vida social, estamos construindo a história e a cultura, corporificadas em nossas identidades sociais, em contextos sócio-históricos específicos, e nos posicionando em relação a interlocutores específicos e diante dos "personagens" que compóem nossas narrativas (Wortham, 2001; Moita Lopes, 2002, 2009). Uma vez que somos as histórias que contamos (e que são contadas sobre nós), ressalto, neste momento, que a organização discursiva da narrativa possui dois níveis de interação dialógica que se entrelaçam: o evento narrado (geralmente relativo às experiências do passado) e o evento da narração em si (quando, no presente, interlocutores se engajam em processos de contar e ouvir histórias) (Wortham, 2001). No evento narrado, o narrador escolhe traços do evento que irá narrar e como irá narrar, definindo assim, não só personagens da narrativa, mas identidades sociais e aspectos culturais que deseja salientar no evento narrado. Mais ainda, cabe lembrar que as identidades no evento narrado e o próprio evento narrado em si também não são histórias fechadas, com uma única possibilidade de existência, mas sim, recortes escolhidos dentro um mosaico de possibilidades de narrativas a serem contadas (Wortham, 2001). Ou ainda, como propóe Alberti (2004, p. 77), "ao contar suas experiências, o entrevistado transforma aquilo que foi vivenciado em linguagem, selecionando e organizando os acontecimentos de acordo com determinado sentido". São essas escolhas discursivas que nomeiam e significam o vivido que é foco do presente estudo e que ratificam a defesa da visão sócio-constitutiva do discurso (Mills, 1997; Wortham, 2001; Moita Lopes, 2002, 2009), pois, como nos lembra Alberti, "conceber o passado náo é apenas selá-lo sob determinado significado, construir para ele uma interpretação; conceber o passado é também negociar e disputar significados e desencadear açôes" (Alberti, 2004, p. 33). 
Embora sejam estudiosos de áreas distintas, tanto Thompson (sociólogo e precursor da história oral) quanto Moita Lopes (lingüista aplicado) acreditam que suas respectivas áreas acadêmicas necessitam de esforços interdisciplinares para melhor compreensão dos fenômenos estudados. Na qualidade de lingüista aplicada, para a presente discussão proponho, então, análises de discursos orais e ouso caminhar pelo terreno fronteiriço da interdisciplinaridade, sugerindo um diálogo entre construtos teóricos da História Oral e da Lingüistica Aplicada (Venn, 2000; Thompson, 1978, 2002; Wortham, 2001; Santos, 2004; Moita Lopes, 2006, 2009). A partir de entrevistas, teremos acesso às narrativas de pescadores artesanais, em que serão contados eventos passados de suas vidas que nos permitiráo ter acesso aos seus conhecimentos, saberes e culturas construídos ao longo dos anos de trabalho em meio à natureza. Esses conhecimentos, construídos localmente e preservados por meio da oralidade, serão o alvo da análise. Na próxima seção, detalho a metodologia de pesquisa, bem como os instrumentos e construtos da Linguística Aplicada que serão mobilizados para a análise dessas narrativas.

\section{Metodologia de pesquisa}

Para a presente discussão, adotamos o paradigma interpretativista de pesquisa, propondo um estudo de caso de base etnográfica (Ludke e André, 1986). A metodologia utilizada para a geração de dados é a da História Oral (Thompson, 1978; Alberti, 2004; Worcman e Pereira, 2006) e a realização de entrevistas semi-estruturadas (Ludke e André, 1986; Worcman e Pereira, 2006), gravadas em áudio com uma duração média de $2 \mathrm{~h}$. Foram entrevistados quatro pescadores artesanais da cidade de Arraial do Cabo (S. Dok, S. Joaquim Torrada, S. Darcy, S. Gamaliel) e um fotógrafo ${ }^{12}$ que se interessa pela preservação dos saberes desses pescadores. A maioria das entrevistas foi realizada nas residências dos pescadores para que eles se sentissem mais à vontade em suas narrativas (Thompson, 1978; Worcman e Pereira, 2006).

12 Esse fotógrafo é cabista de nascença e bolsista do projeto citado no início do artigo. Cabe destacar que ele já desenvolve de forma autônoma um trabalho de resgate das memórias locais por meio de recuperação e restauração de fotografias antigas. 
Durante as entrevistas, propusemos perguntas que pudessem suscitar suas narrativas (Worcman e Pereira, 2006). Os pescadores tiveram, então, oportunidade de realizar diversos relatos orais de histórias de vida ${ }^{13}$, através dos quais pudemos observar o entrelaçar de aspectos da cultura e da natureza, na construção de suas narrativas e do seu saber.

Os pescadores entrevistados não tiveram seus nomes alterados por se tratar de pesquisa sobre histórias de vida e, para assim ser, obtivemos a permissáo para o uso de seus nomes reais, por meio de termos de consentimento. Eles são moradores da cidade de Arraial do Cabo desde que nasceram e trabalharam na pesca por muitos anos. Encontram-se na faixa etária de 80 a 90 anos, e hoje são, em sua maioria, aposentados, bem como considerados talvez a geração mais antiga e tradicional de pesca na cidade. A escolha dos pescadores entrevistados foi feita por sugestão do fotógrafo anteriormente citado e ratificada em relatos pelos próprios pescadores (Thompson, 1978).

Alberti (2004, p. 10) lembra-nos de que podemos avançar em novas descobertas e análises “prestando mais atenção aos 'acontecimentos' e às 'açôes' da entrevista, ao trabalho da linguagem em constituir realidades e ao trabalho de enquadramento da memória”. No exercício da hermenêutica, que "nunca produz a certeza demonstrável" ${ }^{14}$, essas novas descobertas e análises, entretanto, podem cair na armadilha do "relativismo exacerbado" e vertiginoso de que toda interpretação é possível, eximindo o pesquisador da tarefa de analisar, comparar e trabalhar toda fonte de dados ${ }^{15}$. Para tanto, a referencialidade ao passado, buscada pela autora, será discutida no presente trabalho por meio da análise discursiva de pistas indexicais ${ }^{16}$ (Wortham, 2001) que indiquem como o narrador se constrói discursivamente em relação ao evento narrado e aos demais interlocutores. Dentre essas pistas, destaco o seguinte instrumental para análise: referência e predicação; descritores

13 História de vida "é a narrativa construída a partir do que cada um guarda seletivamente em sua memória e corresponde ao como organizamos e traduzimos para o outro parte daquilo que vivemos e conhecemos" (Worcman e Pereira, 2006, p. 203).

14 Idem, op. cit., p. 19.

15 Idem, op. cit., p. 46.

16 Tal qual uma "biruta" (ou manga de vento) aponta a direção do vento, as pistas indexicais apontam como os interlocutores estấo sendo socialmente construídos e como se posicionam na interação (Wortham, 2001). 
metapragmáticos; citações; índices avaliativos e modalização epistêmica (Wortham, 2001).

\section{Análise dos dados}

Nos trechos analisados, o número de sequências de dados ${ }^{17} \mathrm{com} \mathrm{S.} \mathrm{Dok}$ (S. D.) foi maior, por ele desenvolver mais detalhadamente os assuntos que buscávamos pesquisar. Mas além desses dados, também analisamos excertos de S. Joaquim Torrada (S. JT) e S. Gamaliel (S. G.). Ronaldo e Raphael são bolsistas que também participaram da pesquisa.

Seu Dok tem 82 anos e reside em Arraial desde que nasceu. Abaixo, ele comenta a interaçáo que construiu com a natureza nos anos em que trabalhou com a pesca.

01 S. D.: Eu gostei sempre de olhá pra natureza, quando eu tava pescando lá no alto mar, entendeu,

02 no meio dos colegalá, no meio de 20,30 barco, (...), àsvezes, uma nuvem quevemláembaixo, mas

03 nãoéque eu quero botágravataem mim não, quenãosou mais sabido que ninguém, nẫo, (...), mas

04 cada um tem um dom, cada um tem um cuidado, uma proteção, eu semprefui muito cauteloso

05 nessas coisas, tá entendendo, inclusive até tinha o pai de uma nora minha, (...), ele era pescador

06 também, então, ele dizia pros colega assim, 'olha' eles me tratava mais, porque cada um tem um

07 apelido, em qualquer lugar, concorda comigo? Entâo dizia ó, quandoverGigi-queéeu-encolhê

08 a linha, podemos im'bora que vem tempo aî porque de fato, eu matava os peixe, eu tava querendo

09 matar os peixe, mas de vez em quando eu olhava pro alto do céu, sacomé, o céu as vezes tava

10 anuviado, tava meio dobrado, a noite tava aquela confusão, eu tirava conclusão de uma nuvem pra

11 outra, entendeu (...) - (entrevista com S. Dok - 23.01.12)

Podemos perceber nesse trecho que S. Dok destaca, já no início de sua fala, seu interesse por observar a natureza (1. 1), e a partir dela realizar aprendizados (1. 9-11) enquanto pescava. Suas observaçôes e aprendizados rendiam-lhe, inclusive, a credibilidade e a confiança de outros pescadores nas suas decisóes e açóes (1. 7-8). Apesar de querer se construir discursivamente como qualquer outro pescador (1. 2-3), S. Dok reconhece, pela autorreferência e predicação feitas (Wortham, 2001), ser cauteloso (1.4) e experiente

17 Nos dados, poderá ser observado que buscamos uma transcrição o mais próxima possível do falar do pescador para não gerar problemas de "manipulação dos dados". Nesse fazer, contudo, nosso intuito não é de forma alguma analisar as variedades dialetais, nem tampouco salientar estereótipos linguísticos. 
no mar (1. 7-8), características resultantes da observação e dos aprendizados realizados na interação constante com o mar e seus imprevistos. Ou seja, é a construção de saberes e de culturas sobre a pesca, a partir da observação e interação com a natureza (Linsker e Tassara, 2005). Como veremos mais à frente, essas culturas e saberes eram transmitidos e preservados por meio da oralidade.

Muitos assuntos surgiam em nossas entrevistas, mas peculiar atenção foi dada à capacidade dos pescadores de prever o tempo para organizarem suas pescarias. No trecho abaixo, S. Dok faz alguns comentários sobre a observação que fazia do céu, do vento e das nuvens para chegar às suas conclusóes de previsão do tempo.

01 S. D.: Quando tá o céu rabiscado, aquelas listras, a gente trata de rabo de galo, (risos).

02 Pesq.: Como é esse rabo de galo?

03 S. D.: É quando tem, (...), fica cheio de rabiscado, aquelas tiras, e coisa, o pescador diz ó, tá com

04 rabo de galo, vai ter uma quebra de vento', quebra de vento é quando o vento vai calmá, (inaud)

05 então esse vento aquiénordeste, mas o céu tá claro, não tem sinal por enquanto de vento nenhum,

06 entâo,nós temos, eu, como pescador, minha prática, amanhãvai amanhecer umbom dia, também

07 ensolarado, a senhora tá entendendo, se tivesse aqui, virado pro sol, aquele rabo de galo que tô

08 tratando, que tá tudo explicado, 'ó, vai ter uma quebra de vento' (...)

09 Raphael: Então, o rabo de galo indica que pode mudar o tempo...

10 S.D.: Quevai mudarotempo, exatamente, então, quandoéláfora, também, a estreladesloca, nãoé

11 correr não, ela deslocou, de um lado para outro, (...), então, eu tôlá pescando, olha bem, ela correu,

12 a estrela ela deslocou, daqui, aqui é sueste, entâo, a gente diz, 'ó, pode contar que daqui a um ou

13 dois dias vem sueste' daqui de fora, o vento vem de cima da estrela, entendeu, eu tô aqui, o céu tá

14 estrelado, eu tô só olhando, deslocou uma estrela daqui pro sudoeste, "ó, daqui a uns dois dias vai

15 vimsudoeste', ovento vem em cimadaestrela ondeela correu- (entrevista com S. Dok-23.01.12)

No trecho acima, podemos observar S. Dok usando vocábulos típicos da sua atividade profissional e da comunidade onde reside (1. 1, 3-4). São exemplos de índices avaliativos, que são "expressóes ou modos particulares de falar associados a um grupo social em particular. (...) Esses índices podem ser itens lexicais, construçóes gramaticais, sotaques, entre outros" (Wortham, 2011, p. 73). Na linha 6, S. Dok ratifica a análise feita anteriormente de que seus conhecimentos são adquiridos por meio da experiência prática e da observação da natureza $(1.11 ; 13-15)$. Finalmente, acerca da validade ou legitimidade desses conhecimentos, cabe destacar o uso de modalizadores epistêmicos (Wortham, 2001). Enquanto na linha 9, ao se referir à relação entre rabo de galo e mudança de tempo, Raphael (um bolsista) usa o verbo 
auxiliar "poder", para modalizar a possibilidade de algo acontecer (ou não) e, portanto, sugerir menor engajamento com qualquer certeza sobre essa previsão, S. Dok, na linha 10, usa o tempo verbal no presente afirmativo, "vai mudar o tempo", indicando maior certeza e engajamento sobre a validade ou legitimidade do seu conhecimento, por fim, ratificado, ainda, no uso do advérbio "exatamente". Essa certeza e maior engajamento indicados discursivamente significam que suas observaçóes e aprendizados na pesca garantem-lhe maior certeza/ credibilidade sobre sua previsão.

A seguir, podemos ver outro exemplo em que S. Dok comenta sobre seus conhecimentos e cultura construídos sobre previsão do tempo a partir do seu trabalho.

01 S.D.: Eagenteconheceatéadivinhação de tempo também, (...) o tempoéo seguinte, jáaconteceu

02 muito, éo seguinte, não tô dizendo quesô mais do queninguém não, mas, tenho experiência desde

03 novo, né, então, eusempreacostumei, ô, Ronaldoa tá pescandoolhando prosastros, atéuma estrela

04 quando ela desloca, desloca de um lugar pro outro, eu tô vendo, (...), então, (...), eu mato o peixe e

05 tô olhando por baixo pra ver se tá formando alguma barra de vento lá em baixo, né, então, aí eu

06 tomo conta daquela barra de vento, aquele balcão que vem, a diferença que tá fazendo, ela pode

07 voltar e pode suspender, e tô vendo o manejo do vento, porque o vento indica que vai acalmar,

08 quevai ter uma quebra devento, vai ter briga de vento, eu tô olhando, a senhora tá entendendo? E

09 geralmenteé difícil falhar, dizassim, 'essevento é capaz de acalmar' evem sudoeste, entendeu, (...)

10 enquanto isso eu tô matando, tô conversando, (...), e tôolhando prosastros, né, aí quando eu manjo

11 que (inaud) que a nuvem vem sesuspendendo demais, eu digo 'ó, é melhor nós tratar de ir embora,

12 porque vem vento aí, vem uma malha devento lá embaixo', às vez’ pode calmá, pode vir um vento

13 fresco, mas eu tô em terra já, isso várias vezes aconteceu comigo já, vocêlembra quando caiu aquele

14 (inaud) que derrubou essa postaria aqui? Olha só, eu tava lá fora, hein.

15 Ronaldo: Isso em 87?

16 S.D.: Foi, que derrubou aqueles poste tudo, né? (...) Eu tava lá fora, pescando, aí eu olhei, a lua ia

17 de entrada, a lua nova éa lua de entrada, aí vinha aquela nuvem lá embaixo lá, aí eu disse assim, 'se

18 aquela nuvem lá dá pra lua, é tempo que vem aí, capaz de vim noroeste’, porque o vento, (...),

19 cadavento tem um nome, sabe, porque essenoroesteéo piorventoquetem, (...) - (entrevistacom $S$. Dok - 10.01.12)

No trecho acima, o entrevistado começa sua narrativa destacando que, além de outros saberes práticos da pesca, ele "até" faz previsóes do tempo (1. 1). O uso do advérbio de inclusão "até" designa o acréscimo de mais um item aos já elencados. Nesse sentido, enquanto nos apresenta sua narrativa, S. Dok justifica seus saberes e conhecimentos a partir da observaçáo que fazia da natureza durante seu trabalho $(1.3-4 ; 10)$. Ao comentar o que observava na natureza para chegar às suas conclusôes, ele utiliza índices 
avaliativos, como "barra de vento" (1. 5) e "malha de vento" (1. 12), e chega a dar vida a alguns dos elementos citados em sua narrativa - "tomo conta daquela barra de vento", "vai ter briga de vento" e "a nuvem vem se suspendendo demais". Nesse processo de dar vida aos elementos observados, é curioso também ver $S$. Dok se referindo aos ventos como seres de vida própria (1. 7-8), seja porque são identificados por nomes (1. 18-19), seja porque quando diz "eu tô vendo o manejo do vento", indica que é preciso que se tome conta dos ventos porque eles brigam e nesse evento o pescador pode sair prejudicado.

Nesse trecho, encontramos outros exemplos de modalização epistêmica (Wortham, 2001), como o realizado na linha 9, com o uso do predicado cristalizado "é difícil", associado à escolha do verbo "falhar", que indica alto grau de certeza de que naquele cenário virá vento forte. Esse engajamento fica menos evidente quanto à possibilidade de o vento acalmar, quando ele usa o auxiliar "pode", nas linhas 12 e 13. Mais uma vez, ambos os exemplos de modalização significam graus de certeza sobre a cultura da previsão de tempo, fruto do aprendizado empírico.

Entre as linhas 16 e 19, S. Dok faz um breve relato de um episódio em que um vento forte atingiu Arraial do Cabo e derrubou várias árvores e postes. Nesse relato, o pescador comenta que estava em alto mar e que foi a observação que fez da lua e das nuvens que fez com que percebesse que o vento noroeste, responsável pela devastação, estava chegando. Cabe salientar que, uma vez que o vento se torna um quase personagem da história, ele é referido e predicado pelo pescador (Wortham, 2001) como o "pior vento que tem" (1. 19).

Ainda sobre a observação "dos astros", a lua é referida em outros momentos, não somente para as atividades de pesca, mas também para a extração da madeira para fazer agulhas de pesca (Callou, 2010), como vemos, por exemplo, no excerto abaixo.

01 Raphael: S. Gamaliel, fala um pouquinho do tempo certo, da história, de acordo com a lua pra

02 poder tirar a madeira que o senhor tava mostrando que dependendo do dia que tirar, ela racha

03 S. G.: (...) tem a época certa de tirar a madeira, de acordo com as fases da lua, a madeira é retirada

04 no quarto minguante, é a madeira ideal pra isso, até o $2^{\circ}$, no máximo $3^{\circ}$ dia da lua nova, depois

05 dessa época não se mexe mais em madeira, porque há o risco dela trincar, dá bicho, aí, o material

06 (inaud), próprio parasefazer trabalhos com madeira, afasedaluaéo quarto minguante-(entrevista com pescadores - 25.01.12) 
No excerto acima, S. Gamaliel comenta a fase da lua para extração de madeira para confecção de agulhas de pesca. Nas linhas 3 e 4, o pescador utiliza modalizadores epistêmicos (Wortham, 2001), no uso do presente afirmativo "tem a época", "é a madeira ideal", para dar certeza de em qual época a madeira deve ser retirada, pois do contrário, "há o risco dela trincar" (1. 5). Mas a observação da natureza para a construção dos saberes e a previsão do tempo não se restringe à observação do vento, das nuvens e da lua. Como podemos ver no trecho a seguir, há, entre os pescadores, o conhecimento de que os animais também sinalizam mudanças no tempo.

01 S.D.:Ô Ronaldo, olhabem, euvou puxádemais antigo, de um pessoal maisvelho, que eu aprendi

02 também com eles, (...), porque eu sempre gostei, onde tá um mais velho, eu sempre gostei de

03 assuntar, eu gostava memo, por isso que eu panhei um pouco de conhecimento, (...) ele (pescador

04 maisvelho) metia no remo, ele chegava no pesqueiro, sabia que a muçáo tava boa, muçáo porqueas

05 águas, é porque tem a qualidade de água, né, a água quando táao sul ébom pra peixe, equando ela

06 tá a leste já pega o peixe, mas não é tanto, uma disposição boa, não, (...) e tem também outra

07 qualidade de água de fora que não presta, e o pescador sabe disso aí, (...) quando ele encerrava um

08 peixelá na ponta do focinho, olha bem como era a prática dele, encerrava, vinha, o peixe rotava ou

09 botava o bucho prafora, ele dizia, 'ô, meu filho, vamo embora que o tempo vem aî, era dito ecerto

10 osudoestetava em cima, (...) porque o sudoeste ia encapelaro mar, o mar ficava agitado, maresia, e

11 aí ninguém pescava lá, (...) entâo, naquele tempo, quando caía o sudoeste, ninguém pescava lá, a

12 gente sabia porque o peixe que matava dava o sinal, não metia cara, vinha embora, vem vento aí, $\mathrm{e}$

13 vinha o sudoeste (...) - (entrevista com S. Dok - 10.01.12)

Na sequência acima, temos exemplos de índices avaliativos, como nos demais trechos analisados até então, como, por exemplo, "mução", "encapelar" e "amulaçado". No excerto anterior, S. Dok comentava os aprendizados feitos a partir de sua própria observação e prática. Nesse momento, ele destaca que parte do seu aprendizado foi realizada com pescadores antigos (1. 1-3), uma vez que ele usa o advérbio de inclusáo "também" para se referir ao aprendizado com esses pescadores. Tal aprendizado foi realizado por meio da modalidade oral, porque ele "gostava de assuntar" (1. 2-3). Nesse tangente, ele fala sobre a "mução" - qualidade de água para pesca - e faz uma referência e qualificação aos (bons) pescadores, na qual ele se inclui, ao propor que todo pescador sabe reconhecer uma boa mução (1. 7). Durante a narrativa, já nas linhas 8,9 e 13, ele destaca a observaçáo do papel do peixe no reconhecimento da mudança de tempo.

Outro aprendizado feito com os mais velhos diz respeito à "adivinhação do peixe" que era avistado de longe, pelo vigia, durante a pesca. A "adivi- 
nhação do peixe" é um procedimento importante durante a pesca de rede, porque, a depender do tipo de peixe que se aproxima, usa-se determinada estratégia para cercá-lo. O vigia, um dos 9 pescadores de uma companha (Britto, 1999), fica no alto de um morro vigiando a chegada do cardume para avisar aos demais pescadores, que ficam na areia, sobre o tipo de peixe que se aproxima do litoral.

01 S.D.: Então, a mesma coisa éo vigia aqui na praia, o tal do sinaleiro, tem um vigiazinholá em cima

02 do morro (...) ele fica lá em cima, ele tá vigiando, aí ele tá enxergando, ele enxerga um cardume de

03 peixe, dee... mil metros, ou mais, ele alcança com a vista, sacomé, eu tb gostava, eu gosto do vigia,

04 porque ele enxerga longe sabe, ele vê, aí, ele livanta, o pescador aqui nas canoa, sabe logo quando

05 ele vai fazê o sinal, aí vão lá sobe tudo nas canoas, 'ele vai mandá, ele vai mandá, porque ele si

06 livanta, as vezes se ispriguiça, (risos) ele si livanta quando vê o cardume de peixe lááá em baixo, ele

07 vai si ispriguiça, olha pro sol, pra vêseé nuvem né, pra falar o certo, porque a nuvem tem sombra

08 né, (...) a diferença da nuvem, porque o peixeéigual uma mancha de sangue, então, ele num quersi

09 inganar, quando ele falaré porque falou na certa, (...) o povo cá já tá alvoroçado, né, (...) ele tá com

10 uma toalhazinha branca dele no bolso, o peixe vem, desce pra lá, se vira, ele vai, puxa a toalhazinha

11 branca dele aqui e todo mundo fica, aí, ele faz o sinal, e também lá de cima ele faz o sinal, abre os

12 braços, nós trata a manta do peixe, maséo cardume, né, aí, ele diz também que qualidade de peixe

13 é, então se é enchova ele faz sinal que é enchova, quando é xerelete ele faz sinal que é xerelete,

14 quando é xareú tem também o sinal que ele faz pra xaréu, (...) e também diz 'ó tem cinco mil

15 enchova', (...) cinco mil eelevai perder por 500 peixe, dácertinho, néRonaldo?, dá tudo certinho. (entrevista com S. Dok - 10.01.12)

No excerto acima, vemos S. Dok fazendo em narrativa a descrição do trabalho do vigia. Ele começa fazendo referência ao pescador na forma diminutiva (1. 1) que tanto pode indicar estima ao profissional, como também uma referência físico-espacial, porque visto da praia, o vigia, que fica no alto do morro, parece pequenino aos olhos dos pescadores na areia. Em seguida, ele começa a descrever o trabalho do vigia com verbos no gerúndio, "vigiando", "enxergando", indicando uma temporalidade de ação contínua até o momento em que o cardume é avistado e ele usa o tempo presente do indicativo para pontuar esse momento (1. 2-3).

A seguir, o entrevistado justifica porque valoriza e estima o trabalho do vigia: "porque ele enxerga longe" (1. 4). Essa justificativa tanto pode se embasar por ser uma característica necessária à pesca (a visualização do cardume), como também pode ser considerada outra forma de referência e predicaçáo feita ao pescador, que muitas vezes, pelo seu saber intuitivo (Linsker e Tassara, 2005), é considerado clarividente, perceptivo, sagaz, observador. 
S. Dok continua descrevendo a cena (1. 4-9), agora pondo em paralelo as açóes do vigia no alto do morro e dos pescadores na areia da praia. Nesse fazer, enquanto o vigia é descrito de maneira perspicaz e meticulosa, porque ele quer dar o sinal quando tiver certeza do cardume que se aproxima - "ele num quer si inganar, quando ele falar é porque falou na certa" -, os pescadores na areia são descritos e predicados de maneira mais afobada e agitada (1. 9), usando o entrevistado, inclusive, uma citaçáo (Wortham, 2001) indicando o estado de euforia destes à espera do sinal que será mandado pelo vigia (1. 4-5).

Em seguida, o narrador volta a descrever açôes em paralelo: de um lado o vigia, retirando o lenço branco do bolso, e de outro, o peixe no mar, que estava agitado igual aos demais pescadores em terra (1. 9-11), contrapondo predicaçôes aos personagens. E por fim, ele ressalta ainda mais as qualificaçóes e predicaçóes do vigia, novamente por meio do advérbio inclusivo "também", afirmando outra de suas "adivinhaçóes", quando cita que ele também diz a qualidade (espécie) e a quantidade de peixe presente no cardume (ou manta de peixe) (1. 12;14-15). É curioso destacar que, ao longo dessa narrativa, $S$. Dok nos mostrava gestualmente tudo o que falava sobre os sinais do vigia, o que pode ser considerado um exemplo da estreita relação entre corporeidade e discurso (Louro, 2008).

Mormente, todos esses conhecimentos e a cultura oral do cotidiano do pescador são construtos oriundos de seu trabalho e sua interação contínuos com a natureza (Linsker e Tassara, 2005; Callou, 2010). Assim, mesmo quando essas adivinhaçôes são consideradas como um lado místico do pescador, não se pode ignorar que elas também estão atreladas à sua prática e observação cotidiana, já que inúmeros são os relatos sobre acertos na quantidade de peixes presentes nos cardumes. Sobre a identificação do tipo de peixe que se aproximava da costa, além da própria observaçáo do peixe no mar, outros aspectos ou características da natureza eram utilizados pelos pescadores, como podemos ver na sequência a seguir:

01 Ronaldo: Mas uma coisa que eu ainda fiquei curioso aqui foi o seguinte, eu perguntei pelo xaréu,

02 mas, na verdade, o ano é dividido em 12 meses, eu queria saber, qual é a época de cada peixe, se dá

03 mais deumaveznoano, qual períodoébom prapescaria, eu queria saber um pouco dessahistória...

04 S.JT.: (inaud) mês de marçoe abrilébom pra tainhaeanchova, vinha muita quantidade de tainhae

05 anchova, já o mês de novembro, dezembro e janeiro era mais quantidade de xaréu, já fevereiro e

06 março era mais pra tainha e olho de boi, (...), 
07 Raphael: Como o senhor aprendeu a saber qual era o peixe? Vendo ele de longe?

08 S.JT.: A gente quando era mais jovem, a gente conhecia os mais velho, né, então a gente ficava

09 escutando (inaud) aí eles falavam 'ali uma manga de peixe' 'ah, ta lá, aqueleé xaréu' então, a gente

10 (inaud) aprendia que peixe que era, quando era anchova, vinha lá em baixo, aí, eles ficavam

11 mostrando até a gente ver, então, a gente sabia que era anchova (...). -

(entrevista com pescadores - 25.01.12)

No trecho acima, Ronaldo suscita uma pergunta, já imaginando que outro elemento presente na "adivinhação do peixe" era a consciência da sazonalidade de certos cardumes pela costa (1. 1-3). Nesse momento, S. Joaquim Torrada, pescador de 92 anos e que trabalhou como vigia, apresenta uma explicação que sugere uma racionalidade no trabalho (1.4-6). Nesse momento, percebe-se a construção de uma cultura pelo pescador que, apesar de não conferir a ele o "ar místico" observado na transcrição com S. Dok, é igualmente um conhecimento resultante da observação e interação contínuas com o meio ambiente.

Destaco também que, mais uma vez, a cultura da oralidade, presente nas conversas com pescadores mais velhos, tal qual citada por S. Dok, aparece como resposta aos aprendizados feitos pelos entrevistados. Entre as linhas $10 \mathrm{e}$ 13, S. Joaquim Torrada narra como aprendeu a identificar a espécie de peixe no cardume avistado. Nesse caso, o entrevistado se constrói no conjunto de pescadores jovens fazendo referência a um grupo de pessoas e marcando a temporalidade de um tempo passado (1. 9-10). Na breve narrativa, ele diz que o aprendizado era feito pela escuta aos mais velhos e experientes e pela observação do trabalho destes em ação (1. 8-11).

$\mathrm{Na}$ última sequência analisada, temos uma longa narrativa vivida por $\mathrm{S}$. Dok em alto-mar. Nela, podemos perceber, uma vez mais, a importância de conhecimentos e culturas construídos na interação contínua com a natureza.

01 S. Dok.: Porque a experiência vale muito, porque agente tem aquela consciência viva, da certeza,

02 que vai dar certo ou não, ele não vai ficar em dúvida, porque aquilo aliéuma coisa que nasceu dele,

03 que ele meteu a mão pra saber o que é e o que não é.

04 Pesq.: O aprendizado que o senhor fez no seu dia a dia, né?

05 S. Dok.: No dia a dia, no dia do mar, se eu disser que aquié pedra, é pedra, aqui é pau, é pau, por 06 quê? Pela minha experiência, a senhora tá entendendo? Nãoé por meio de estudo, éna natureza 07 mesmoqueeuaprendi, (...) na naturezadeDeus, (...) eo dono dobarcochamavaJ., (...) eleconfiava 08 em mim, porque eu sempre tive o meu, o meu cartaz com eles, eles sabia que eu era, que eu tinha a

09 minha sabedoria, né, aí, nós carreguemo o barco, (...) e nós tinha um pesqueiro aqui fora à leste, a

10 gente sai daqui e gasta $5 \mathrm{~h}$ de viagem pra matar enchova, e esse rapaz que tá doente, ele (inaud) o 
11 leme do barco pra governar, ele é um camarada muito de facilidade, não tem aquele heroísmo,

12 aquela vivacidade, no leme, e responsabilidade, a embarcação vai lá e vem cá, (...) e eu de cá tô

13 vendo tudo e tá me dando aflição, (...), nós tinha saído daqui meio-dia e tinha que chegar lá cinco

14 hora da tarde, cinco hora deviagem dentro do mar, eu tô olhando, aí, daquia pouquinho, deu uma

15 certa hora, eu olhei pro vento, calmou daqui nordeste, e ia vim um vento contrário daqui do

16 sudoeste, tudo enfumaçado, sabe, a serração vem galgando por cima, e eu disse assim 'J., ó quem

17 vem lá, ó o sudoeste, o nordeste calmou, o sudoeste vem lá, vai dá serração aî', ó o barco tá

18 escrevendo muito vai lá ecáaí eu falei ‘deixa (inaud) que não tem responsabilidade!'(...), porque eu

19 não queria panháoleme, porque ele não medeu, nãovou me meter a intrujão, elequeéo dono, ele

20 que se vira, 'ô J., porque você não póe logo (inaud) pra essas ilhas pra esse morro que tem aqui?

21 Porque se cair e fechar serração nós tamo dentro de uma ilha', 'aaah, major...' 'J., você faz isso que

22 eu tô te dizendo, rapaz!' 'tá beeem', graças a Deus a serração desmanchou, e vai o barco lá e vem

23 aqui, escrevendo, e aquilo me dando aflição, (...) daqui a pouco, entrou pela noite, ea gente calcula

24 a viagem pra chegar lá, 'J., que horas que tem aí, J.?' 'Major, já é sete horas' 'Sete horas!? E nós

25 náo tamo nem no pesqueiro ainda, nem na metade (do caminho), J.... tá vendo o que faz a sua

26 responsabilidade...' aí, ele fez assim 'ah, vou desligar o motor, já tamo perdido, vamo ficá aqui

27 mesmo' (...), e eu disse 'o que, J?', e ele, 'ah, major, nós tamo perdido, vamo ficá aqui memo' ‘aaah,

28 não me diga isso, J, você não panhou, não passou a mão no leme primeiro do que eu, já era pra

29 gente ta lá,J! Já devia tá lá no pesqueiro chamado 'burro', poxa!', (...), olha, mas eu sempre andava

30 preparado, olha o que é a prática, dentro da minha vasilha, eu usava sempre um chumbo, de um

31 quilo mais ou menos, que tem umalinhaamarrada, (inaud) de 40 braça mais ou menos, eu andava

32 sempre prevenido, e esse chumbo, eu derreti o chumbo e fazia igual um coração, e fazia um buraco

33 no fundo, entendeu, olha só a experiência, por isso que digo que a experiência, équase muito mais

34 que... a teoria, eu fiz, aprendicomos portugueses, (...), então, quando tinhasonda, eraassim, (...) no

35 buraco, no fundo, eu enchia de sabão, e no meu barco, andava sempre assim, 'ó J., quer ver como

36 nós, onde nós tamo?...' botei no sabão e larguei, porque sabão dá sinal de tudo, quando é areia, é

37 areia, quandoélama, élama, quandoécascalho, equandoépedra, tambémé pedra, então, eu botei,

38 virando assim 'ó J.', a lama, ficou tudo ali, no sabão, (...), ‘aqui, ó, tamo na lama, e agora, J.?’ E $\underline{\text { o }}$

39 céu estrelou, ficou tudo estrelado, aí, eu pela minha prática, graças a Deus disse assim 'J., vc disse

40 que nós tamo perdido, mas não vamo ficá não, nós vamos chegar no pesqueiro mas, ó, vc panha o

41 leme, não tira a mão daí, J., você tá vendo essa estrela aquie? Porque (inaud) horas mais ou menos

42 tem uma estrela grande igual à estrela Dalva, 'ó, J., vocêvai andá 20 minutos em cima dessa estrela,

43 eqdo fizer 20 minutos, vc pára pra eu sondar, nós vamos chegar em cima do pesqueiro', de noite

44 nós não via nada, 'major, ó, já faz vinte minuto', 'pára' eu soltei a primeira, vez, era lama e 24

45 braça, e aonde nós ia pescar era 42 braça, de fundura, aí, joguei, papapapapa, 'ó, J., já tá em 25

46 braça, já tamo ficando fundo, ó, a linha do navio ainda não tá não, mas vamo imbora, bota nesse

47 rumo, mais 20 minuto e pára’ só sei que já foi pra mais de 30 braça, aí, quando eu olhei assim eu vi

48 um navio aqui assim 'ó, agora, nós já vamo panhá a primeira linha do navio, tá vendo J., viu o

49 descuido, vamo embora', foi, foi, foi, foi, andamo mais 20 minuto, 'ó, segunda linha do navio', de

50 noite, de noite, só pela prática, aí, andamo, andamo, andamo, quando vi, 38 braça, 'ó, nós já tamo

51 chegando perto do pesqueiro, hein' andamo, andamo, puxei, 'ó cascalho grosso, (..) tá vendo, J.,

52 olha aqui, ó, vai em cima da estrela', a estrela viva na proa do barco, não precisou nem mais parar,

53 maisum cadinho, oscompanheiroda (inaud), lá tinha muito barco pescando, aíveioaquelagritaria 
54 “ÊÊÊÊÊÊE" eeu, ó os barco lá, viu? ViuJ., eu vou botá minhasonda aqui pra dentro’, chegamo no 55 pesqueiro umas $10 \mathrm{~h},(. .$.$) tá vendo J., o queéa facilidade, vocêainda queria parar o barco e ficarà$

56 deriva da água, J., no mar, não se dá por perdido, não!' (...) sabe quantos quilos de peixe matamo 57 nesse dia? $500 \mathrm{~kg}$ de peixe, carregamo o barco, e você vê na minha prática, ol ha eu vivi tanta coisa 58 dentro do mar, (...) - (entrevista com S. Dok - 01.02.12)

Nessa longa narrativa, S. Dok inicia chamando atenção para a experiência prática como argumento e causa para a certeza de suas conclusóes e decisóes (1. 1). Ele continua destacando o aprendizado empírico em detrimento do formal (ou teórico) (1. 6-7), mas, curiosamente, faz referência ao pescador em $3^{\text {a }}$ pessoa (ele) e não mais em $1^{\text {a }}$ pessoa, o que também é uma forma de modalizaçáo epistêmica e lhe confere, mesmo que momentaneamente, um status de narrador onisciente (Wortham, 2001). Em seguida, ele volta a narrar em $1^{\text {a }}$ pessoa e, nas linhas 8 e 9 , justifica porque os pescadores confiavam nele e começa a relatar sua longa narrativa, na qual demonstrará a vantagem dos aprendizados realizados na interaçáo com a natureza.

Para isso, contudo, ele faz uma contraposição entre a referenciação e a predicação valorativa a si mesmo $(1.8-9 ; 13)$ e a feita sobre seu companheiro de pesca (1. 12 e 13) de maneira menos valorativa, porque este não teria o "heroísmo", "a vivacidade" ou a "responsabilidade" no leme. Em seguida, o pescador descreve uma cena em que faz referência ao vento como um personagem e cita sua interação com ele (1. 15-18), dizendo, por exemplo, "eu olhei pro vento". A chegada do personagem "vento sudoeste" (1. 17) aponta um momento de atrito entre ele e seu companheiro (1. 18-20), quando ele começa a questionar a condução da embarcação e a dar suas sugestóes. É curioso perceber que, nas citaçóes que $S$. Dok faz, seu companheiro o chama de "major" (1. 21; 24; 27), uma referência que indica alguma hierarquia. E essa hierarquia parece ser sinalizada também em outros momentos, pois apesar de S. Dok não tomar a condução direta do barco, ele faz sua caracterização e referenciação como alguém na posição de mestre, de observador e avaliador das atividades (1. $13 ; 18 ; 22 ; 24 ; 25)$. Em contrapartida, o companheiro é referenciado, predicado ou caracterizado em suas açóes como um aprendiz (1. 22; 24-27) ou até mesmo como um irresponsável (1. 26-29).

Contrastando com a irresponsabilidade de J. (seu companheiro de viagem), S. Dok aponta sua previdência e experiência, ao levar consigo objetos que poderiam ajudá-lo em situaçóes inóspitas (1. 29-32), afirmando em uma autopredicação, pois sempre andava prevenido e preparado. Uma 
vez mais, S. Dok ressalta a prática em detrimento da teoria (1.33-34), e em seguida demonstra empiricamente ao seu companheiro como ele descobrirá onde estão (1.35-36) e como fará para chegar ao pesqueiro pretendido. Para isso, ele usará uma sonda improvisada, aprendida com os portugueses (1. 33-34), e a observação do céu (1. 39). É interessante destacar que, embora não usassem carta de navegação nem astrolábio ou bússola, os pescadores conseguiam se localizar no mar e chegar aos seus destinos pela consciência dos pontos cardeais, a posição do farol, das estrelas no céu e dos montes ou pedras, ou ainda com auxílio dos ventos e das marés que também lhe eram conhecidos. Assim, mesmo não tendo acesso ao saber formal, o pescador artesanal constrói sua cultura, seu saber e sua tecnologia na interação que faz com a natureza, e de forma muito menos impactante.

Em seguida, ele dá instrução a J. para conduzir o barco orientado por uma dada estrela e, de tempos em tempos, eles param para verificar com a sonda improvisada a profundidade do local onde estavam (1. 42-43). S. Dok narra como percebia o aumento da profundidade (medida em braças) até que chegam ao referido pesqueiro (1. 51-53). Nesse ínterim, o pescador faz nova referência à validade de sua prática (1.49-50), ao afirmar com o advérbio de exclusão "só" que "só pela prática, aí, andamo, andamo".

Com essa última sequência, podemos enumerar vários exemplos de situaçóes em que os pescadores relataram seus saberes e culturas aprendidos em meio à pesca e em equilíbrio com a natureza. Esses conhecimentos e culturas são construídos de forma empírica e transmitidos por meio da oralidade (Silva, 2010; Callou, 2010), como foi citado em alguns excertos. Durante a análise de dados, também foi ratificada a importância desses saberes para o exercício profissional desses sujeitos, o que envolve um profundo conhecimento de ordem sócio-ambiental e de uso dos recursos naturais sem a degradação ambiental (Linker e Tassara, 2005; Callou, 2010).

\section{Considerações finais}

Segundo Alberti (2004, p. 79), ao transformar lembranças em discurso, “a linguagem não 'traduz' conhecimentos e ideias preexistentes. Ao contrário: conhecimentos e ideias tornam-se realidade à medida que, e porque, se fala". 
Desse modo, o trabalho com narrativas requer uma atitude constantemente reflexiva sobre as consideraçóes alcançadas (Santos, 2004; Moita Lopes, 2006; Fabrício, 2006).

Na presente discussão, pudemos observar a construção de culturas e conhecimentos empíricos por pescadores artesanais em seu cotidiano, bem como a disseminação desse saber por meio da oralidade. Mais ainda, pudemos ressaltar a importância desses saberes sócio-ambientais para a construção da história dessas pessoas e da comunidade. Aberti (2004, p. 46) nos alerta, contudo, sobre a armadilha de tomar uma única entrevista ou grupo de entrevistas como resposta "definitiva e completa daquilo que aconteceu no passado". Em algumas entrevistas, por exemplo, foram citados outros sujeitos sociais - os caringôs (pescadores de fora) - que vêm dividindo há algum tempo as experiências e espaços da referida cidade e eram predicados de maneira menos valorativa. Ademais, tivemos ciência de barcos de pescadoras que também dividem esse espaço social e que chamaram nossa atenção para a invisibilidade da figura feminina nos discursos até aqui analisados. Podemos, então, desdobrar outra estreita relaçáo entre saberes/culturas da pesca artesanal de Arraial do Cabo e as identidades sociais e corpos que perpassam essas redes de saberes (Louro, 2008).

Pretendemos, assim, continuar promovendo o diálogo interdisciplinar, ratificando as características teórico-metodológicas da História Oral, que prima pela análise democrática e complexa (Thompson, 1978) ao analisar discursos e vozes de outros sujeitos sociais. Sobretudo, ressaltamos a necessidade de reflexão sobre questóes éticas como, por exemplo, quem são os reais beneficiados com os conhecimentos produzidos a partir dessas narrativas (Moita Lopes, 2006) ou que corpos/ subjetividades são autorizados a participar das atividades de pesca e a construir saberes legitimados sobre ela. É sobre esses desdobramentos que continuaremos a nos debruçar.

\section{Referências}

ALBERTI, V. Ouvir contar: textos em história oral. Rio de Janeiro. FGV editora, 2004.

BAKHTIN, M. Marxismo e filosofia da linguagem. Versão utilizada: tradução. Hucitec, 1929/1992. 
BRITTO, R. C. de C. Modernidade e Tradição - construção da identidade social dos pescadores de Arraial do Cabo/ RJ. Niterói: EdUFF, 1999.

CALLOU, A. B. F. Povos do mar: herança sociocultural e perspectivas no Brasil. Ciência e Cultura, v. 62, p. 45-48, 2010.

EAGLETON, T. A ideia de cultura. São Paulo. Editora UNESP, 2005.

FABRÍCIO, B. F. "Linguística Aplicada como espaço de desaprendizagem: redescriçôes em curso". In.: MOITA LOPES, L.P. da (Org.). Por uma Linguistica Aplicada Indisciplinar. São Paulo: Parábola, 2006.

FARACO, C. A. Linguagem \& Diálogo: as ideias linguisticas do círculo de Bakhtin. São Paulo: Parábola Editorial, 2009.

FOUCAULT, M. A ordem do discurso. São Paulo: Ediçôes Loyola, 1971/2003.

GRAYLING, A. C. Wittgenstein. São Paulo: Ediçôes Loyola, 1996.

LINSKER, R. e TASSARA, H. O mar é uma outra terra. São Paulo: Terra Virgem, 2005.

LOURO, G. L. Gênero, sexualidade e educação: uma perspectiva pós-estruturalista.

Petrópolis: Vozes, 1997.

. Um corpo estranho: ensaios sobre sexualidade e teoria queer. Belo Horizonte: Autêntica, 2008.

LÜDKE, M. e ANDRÉ, M. E. D. A. Pesquisa em educação: abordagens qualitativas. São Paulo: EPU, 1986.

MILLS, S. Discourse. London: Routledge, 1997.

MOITA LOPES, L. P. da Identidades fragmentadas: a construção discursiva de raça, gênero e sexualidade em sala de aula. Campinas, SP: Mercado de Letras, 2002.

- "Linguística Aplicada e vida contemporânea: problematizando os construtos que têm orientado a pesquisa". In.: (Org). Por uma Lingüistica Aplicada Indisciplinar. São Paulo: Parábola, 2006.

. A vida sociocultural em construção: interação, situacionalidade, alteridade e ética. In.: PEREIRA, M. da .G .D. et al. (Org.). Discursos socioculturais em interação: interfaces entre a narrativa, a conversação e a argumentação: navegando nos contextos da escola, saúde, empresa, mídia, política e migraçâo. Rio de Janeiro: Garamond, 2009.

SANT'ANNA, A. R. "Contaçâo de história: vida e realidade” In.: PIETRO, B. (Org.). Contadores de história - um exercício para muitas vozes. Rio de Janeiro: 2011.

SANTOS, B. de S. "Do pós-moderno ao pós-colonial. E para além de um e de outro". Travessias. Centro de Estudos Sociais: Universidade de Coimbra, \#6/7, 2004. 
SILVA, G. D. da. "Pescar, catar e debulhar: os saberes da pesca artesanal em comunidades tradicionais da RESEX Acau - PB/Goiana - PE". Trabalho apresentado na 27a. Reunião Brasileira de Antropologia, realizada entre os dias 01 e 04 de agosto de 2010, Belém, Pará, Brasil.

THOMPSON, P. The voice of the past-Oral history. $3^{\mathrm{a}}$ ed. New York: OUP, 1978/2000.

. História oral e contemporaneidade. In.: História Oral, vol. 5, p. 9-28, 2002.

VENN, C. Occidentalism. Modernity and Subjectivity. Londres: SAGE, 2000.

WORCMAN, K. e PEREIRA, J. V. História falada: memória, rede e mudança social. São Paulo: SESC SP. Museu da Pessoa, 2006.

WORTHAM, S. Narratives in action. A strategy for research and analysis. New York and London: Teachers College, Columbia University, 2001.

Resumo: Visando à articulação de construtos teóricos da História Oral e da Lingüística Aplicada (Thompson, 1978; Moita Lopes, 2006) e ciente da importância dos saberes sócio-ambientais construídos por pescadores artesanais no seu cotidiano (Linsker e Tassara, 2005; Callou, 2010), o presente artigo objetiva analisar a construção discursiva de saberes e culturas por pescadores artesanais, em interaçáo com a natureza, na cidade de Arraial do Cabo. Para tanto, assumo a visão sócio-constitutiva do discurso (Mills, 1997; Fabrício, 2006) e me proponho a analisar, a partir de pistas indexicais (Wortham, 2001) as narrativas contadas pelos referidos pescadores em entrevistas semi-estruturadas (Ludke e André, 1986; Worcman e Pereira, 2006). O propósito dessa discussão é lançar um olhar mais democrático e complexo (Thompson, 1978; Alberti, 2004) sobre os fenômenos socioculturais e socioambientais (Moita Lopes, 2006/2009).

Palavras-chave: pescadores artesanais; cultura de pesca; saberes socioambientais.

\title{
"I drew the conclusion from one cloud to another": A reflection on histories, knowledge and cultures of artisanal fishing in Arraial do Cabo
}

\begin{abstract}
In order to articulate Oral History and Applied Linguistics theory constructs (Thompson, 1978; Moita Lopes, 2006) and aware of the importance of social-environmental knowledge built by artisanal fishermen in their daily lives (Linsker e Tassara, 2005; Callou, 2010), this article aims to analyze the discursive construction of knowledge and cultures by artisanal fishermen, in interaction with nature, in the city of Arraial do Cabo. For this, I assume the socio-constitutive view of discourse (Mills, 1997; Fabrício, 2006) and I propose to analyze by means of indexical cues (Wortham, 2001) the narratives told by those fishermen in semi structured interviews (Ludke e André, 1986; Worcman e Pereira, 2006). The purpose of this discussion is to present a more democratic and complex look (Thompson, 1978; Alberti, 2004) on the social-cultural and social-environmental phenomena (Moita Lopes, 2006/2009).
\end{abstract}

Key words: artisanal fishermen; fishing cultures; socio-environmental knowledge.

Recebido em: 12/03/2012

Aprovado em: 27/04/2012 